\title{
Penentuan Jarak Baca Terbaik Pada Sistem Pemindai Berbasis Larik Sensor Ultrasonik
}

\section{Galih Setyawan $^{1}$, Trias Prima Satya ${ }^{1}$, Muhammad Rifqi Al Fauzan ${ }^{1}$, Fitri Puspasari ${ }^{1}$, Imam Fahrurrozi ${ }^{2}$, Estu Muh Dwi Admoko ${ }^{1}$}

${ }^{1}$ Program Studi Metrologi dan Instrumentasi, Departemen Teknik Elektro dan Informatika, Sekolah Vokasi, Universitas Gadjah Mada, Yogyakarta, Indonesia

${ }^{2}$ Program Studi Komputer dan Informatika, Departemen Teknik Elektro dan Informatika, Sekolah Vokasi, Universitas Gadjah Mada, Yogyakarta, Indonesia

\section{Info Artikel}

\section{Histori Artikel:}

Diterima: 27 November, 2019

Direvisi: 10 Desember, 2019

Diterbitkan: 1 Maret, 2020

\section{Kata kunci:}

larik sensor sensor ultrasonik sistem pemindai

\begin{abstract}
ABSTRAK
Telah dilakukan penelitian mengenai penentuan jarak baca terbaik pada sistem pemindai berbasis larik sensor ultrasonik. Penelitian ini sebagai langkah awal pembuatan sistem pemindai kerataan permukaan suatu objek. Sensor ultrasonik dibuat larik dengan mengadaptasi kerja dari scanner komputer. Jumlah ultrasonik yang digunakan adalah sebelas buah sensor. Jumlah sensor yang cukup banyak membutuhkan jumlah port yang lebih banyak juga, sehingga dipilih Arduino Mega sebagai mikrokontrolernya. Larik sensor ultrasonik akan menghasilkan data sejumlah sebelas buah data. Data akan ditampilkan dan disimpan dalam bentuk excel melalui aplikasi Parallax Data Acquisition tool (PLX-DAQ). Variasi jarak yang digunakan adalah setiap kenaikan $5 \mathrm{~cm}$, dimulai dari $5 \mathrm{~cm}$ sampai $50 \mathrm{~cm}$. Dari data yang diperoleh kemudian dianalisis dengan melihat perbandingan persentase error pembacaan larik sensor ultrasonik terhadap nilai standar jaraknya. Dari hasil variasi jarak yang dilakukan diketahui jarak ideal yang baik digunakan dalam sistem pemindai. Hasil menunjukkan bahwa jarak baca terbaik dalam penelitian ini adalah pada jarak $50 \mathrm{~cm}$. Hal ini dibuktikan dengan nilai persentase error yang lebih kecil.
\end{abstract}

Research has been conducted on determining the best reading distance of the scanning system based on ultrasonic sensor array. This research is a first step in making an object's flatness scanning system. Ultrasonic sensor are made in array by adapting the work of a computer scanner. The amount of ultrasonic used is eleven sensors. The large number of sensor requires a higher number of ports as well, so Arduino Mega was chosen as the microcontroller. Array ultrasonic sensor will read and generate eleven data. Data will be displayed and stored in an excel range via the Parallax Data Acquisition tool (PLX$D A Q)$ application. The distance variations used are every $5 \mathrm{~cm}$, starting from $5 \mathrm{~cm}$ to $50 \mathrm{~cm}$. From the data obtained is then analyzed by looking at the comparison of the percentage error of reading the ultrasonic array against the standard value of the distance. From the result of the distance variations carried out will be known a good ideal distance and can be used in the scanning system. The result show that the best reading distance in this study is at a distance of $50 \mathrm{~cm}$. This is evidenced by the value of a smaller error percentage. 


\section{PENDAHULUAN}

Penelitian ini merupakan tahap awal dari pembuatan sistem pemindai kerataan permukaan suatu objek berbasis larik sensor ultrasonik. Tujuan penelitian ini adalah untuk mengetahui jarak pembacaan larik sensor yang terbaik dari berbagai variasi jarak yang dilakukan. Sehingga penelitian ini menjadi dasar bagi penelitian selanjutnya. Penelitian selanjutnya akan dikembangkan dengan larik sensor ultrasonik yang dapat bergerak secara horisontal saat proses pemindaian. Pemindai menurut Kamus Besar Bahasa Indonesia (KBBI) berarti alat yang digunakan untuk memeriksa, mengamati atau mengopi gambar dalam bentuk digital. Menurut Junaidi, dkk.(2015) pemindai 3D terdiri dari dua jenis, yaitu pemindai laser dan pemindai dengan sensor ultrasonik. Pemindai laser mempunyai kelemahan, salah satunya adalah membutuhkan biaya yang tidak murah. Sedangkan pemindai dengan menggunakan ultrasonik akan menghasilkan alat pemindai yang lebih ekonomis. Salah satu penelitian yang menggunakan sensor ultrasonik untuk pemindai 3D adalah munir dkk.(2015). Walter dan Schweinzer (2015) menggunakan compact ultrasonic 3D sensor untuk mengenali bentuk dan arah objek. Peneltian lain tidak menggunakan sensor ultrasonik HC-SR04 dalam sistem pemindainya, namun menggunakan VL53LOX untuk membangun pemindai 3D (Maria dan Susianti, 2019).

Sensor ultrasonik merupakan sensor yang telah banyak digunakan peneliti untuk berbagai macam aplikasi. Penggunaan dan pemograman yang mudah mejadi salah satu alasan sensor ini banyak digunakan. Beberapa contoh pemanfaatan sensor ultrasonik ini adalah untuk aplikasi pemantau ketinggian air (Arief, 2011), (Alawiah dan Tahtawi, 2017) dan aplikasi pemandu parkir (Pindrayana, 2018).

Sensor ultrasonik bekerja dengan cara memancarkan gelombang ultrasonik dari salah satu bagian sensor (transmitter) dan diterima kembali oleh bagian lain (receiver) setelah terpantul dari suatu objek (Puspasar, dkk., 2019). Sensor HC-SR04 ini mempunyai kemampuan mengukur jarak antara $2-400 \mathrm{~cm}$ dengan sudut pantul pengukuran $15^{\circ}$ (Fikri,dkk., 2018). Pada dasarnya yang dibaca oleh sensor ultrasonik adalah waktu tempuh gelombang bolak-balik dari transmitter sampai ke bagian reciever. Namun biasanya hasil output yang ditampilkan diseuaikan dengan kebutuhan yang diperlukan. Sebagai contoh, output dapat dalam satuan $\mathrm{cm}$, $\mathrm{mm}$, liter dan lainnya. Gambar 1 menunjukkan prinsip kerja dari sensor ultrasonik.

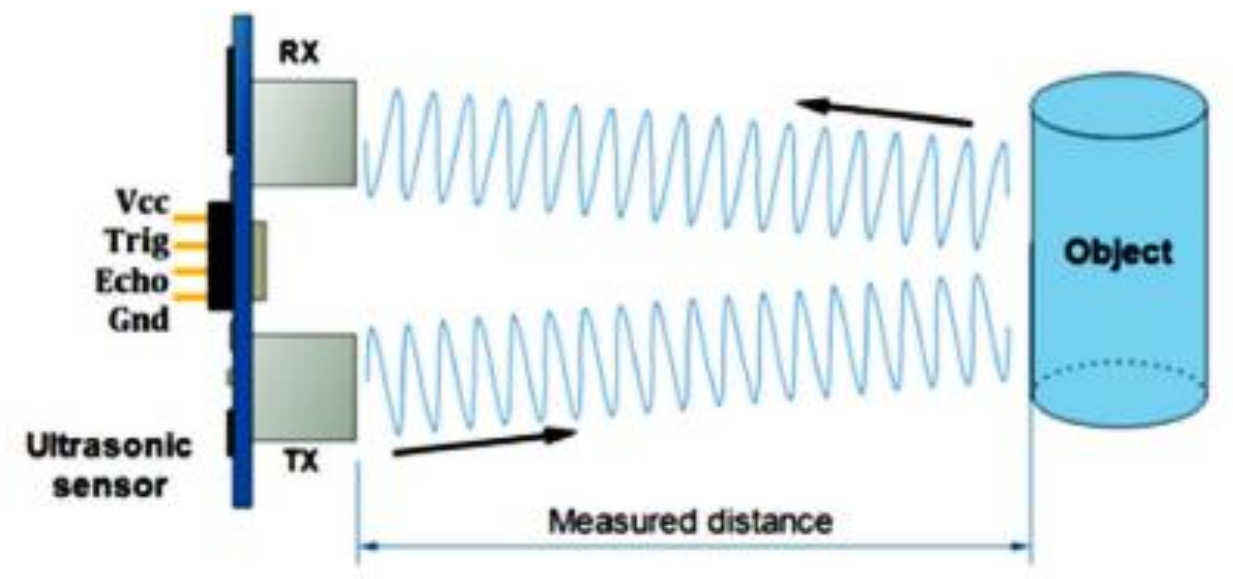

Gambar 1. Prinsip Kerja dari Sensor Ultrasonik (Renaldi, dkk., 2017)

Sensor ultrasonik dalam kerjanya selalu disandingkan dengan mikrokontroler. Mikrokontroler merupakan suatu sistem komputer fungsional dalam sebuah chip (Ohoiwutun, 2018). Dalam penelitian ini mikrokontroler yang digunakan adalah Arduino Mega. Arduino Mega digunakan karena mempunyai port yang lebih banyak. Misalnya bila dibandingkan dengan Arduino Uno. Hal ini juga menyesuaikan dengan banyaknya sensor yang digunakan. Arduino Mega 2560 merupakan mikrokontroler yang berbasis pada ATmega 2560 yang memiliki 54 pin digital input dan output (Arifin, dkk., 2016) dan (Iskandar, dkk., 2017). 


\section{METODE}

Alat dan bahan yang digunakan dalam penelitian ini terdiri dari hardware dan software. Hardware yang digunakan terdiri dari:

1. Larik Sensor Ultrasonik

2. Kabel Penghubung

3. Arduino Mega

4. Kabel USB

5. Papan Sebagai Objek

Sedangkan software yang digunakan adalah :

1. Arduino IDE

2. PLX-DAQ

Larik sensor ultrasonik dibuat dengan cara memasang sensor ultrasonik secara berdekatan satu sama lainnya. Sensor ultrasonik yang digunakan berjumlah sebelas buah. Harapan dari penelitian ini setiap sensor ultrasonik mampu membaca dengan baik. Desain, pengkabelan dan rancangan kerja larik sensor ultrasonik ditunjukkan pada gambar 2, 3, dan 4. Gambar 2 menunjukkan sensor ultrasonik yang tersusun secara vertikal. Kedepannya, larik sensor ini mampu bergerak secara horisontal yang akan bekerja seperti kerja scanner pada komputer. Dalam hal ini kelak sistem akan melakukan pemindaian pada permukaan suatu objek. Untuk itu perlu diketahui jarak pembacaan terbaik. Gambar 3 menunjukkan pengkabelan pada mikrokontroler Arduino Mega 2560. Gambar 4 menunjukkan proses pemindaian dengan cara masing-masing sensor (sebelas sensor) mengirimkan data jarak suatu objek.

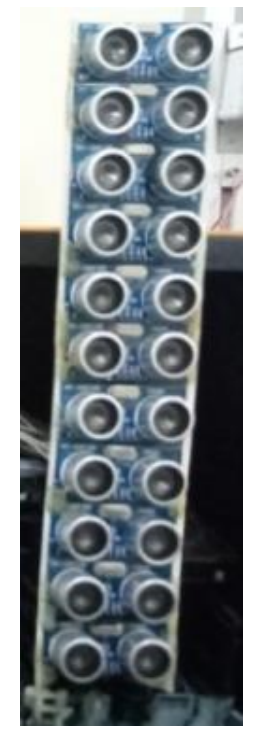

Gambar 2. Konfigurasi Larik Sensor Ultrasonik

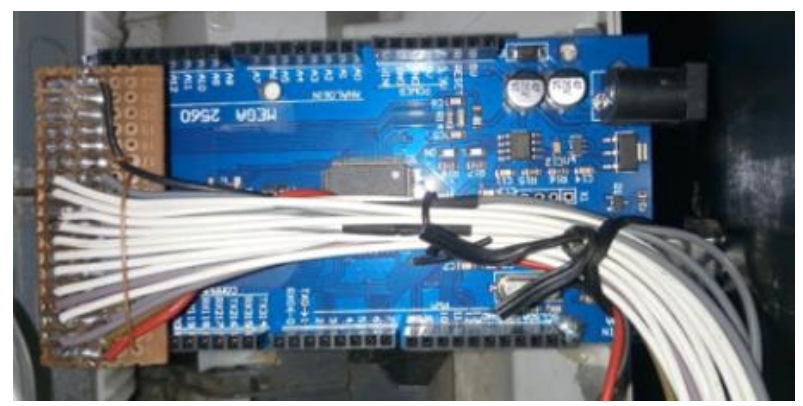

Gambar 3. Pengkabelan Antara Sensor Ultrasonik dan Arduino Mega 


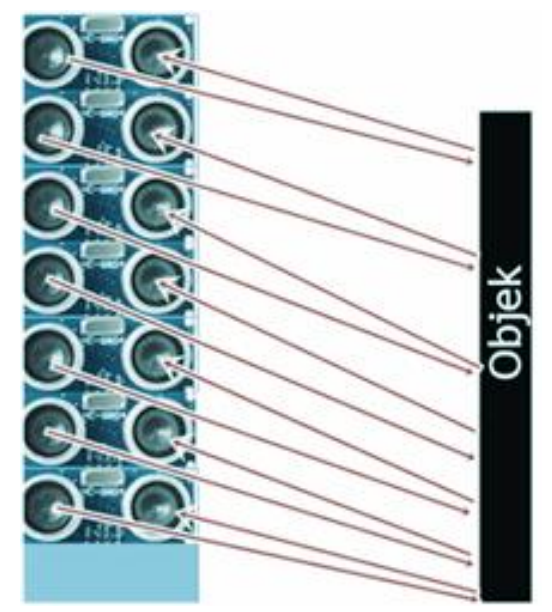

Gambar 4. Prinsip Kerja Larik Sensor Ultrasonik

Sistem larik sensor ultrasonik dapat bekerja dengan cara mengikuti perintah pada program Arduino IDE yang telah dibuat. Data ditampilkan dan disimpan secara otomatis melalui aplikasi Parallax Data Acquisition Tool (PLX-DAQ). PLX-DAQ merupakan aplikasi sistem akuisisi data yang diintegrasikan dengan spreadsheet excel (Fachri, dkk., 2015). Aplikasi ini sangat membantu pengguna karena dapat menampilkan dan menyimpan data dari sebelas sensor yang digunakan secara realtime. Aplikasi ini dapat digunakan untuk monitoring, analisis dan kontrol (Mira dan Swarnalatha, 2018). Selain itu perangkat ini mampu memplot grafik dari data yang dikirikan. Gambar 5 menunjukkan gambar antarmuka dari PLX-DAQ. Data yang dihasilkan kemudian dianalisis, salah satunya adalah mengenai nilai kesalahan/error. Persamaan 1 menunjukkan rumus untuk mencari nilai dari error.

$$
\text { Error }=\frac{U-S}{S} \times 100 \%
$$

Dengan U dan S masing-masing adalah Uji (hasil baca dari larik sensor ultrasonik) dan Standar jarak yang digunakan. Dalam hal ini pengukuran jarak dilakukan dengan menggunakan mistar. Tahap penelitian secara keseluruhan dapat dilihat pada gambar 6 .

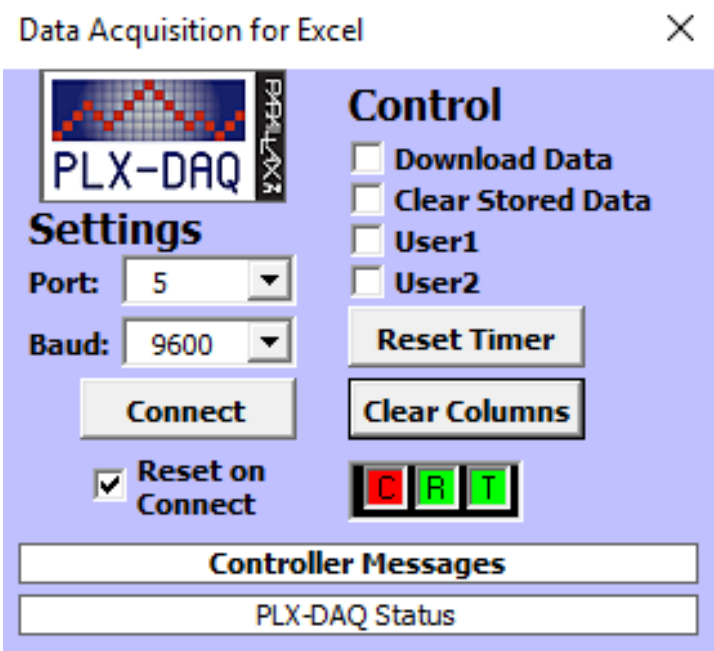

Gambar 5. Antarmuka dari PLX-DAQ 


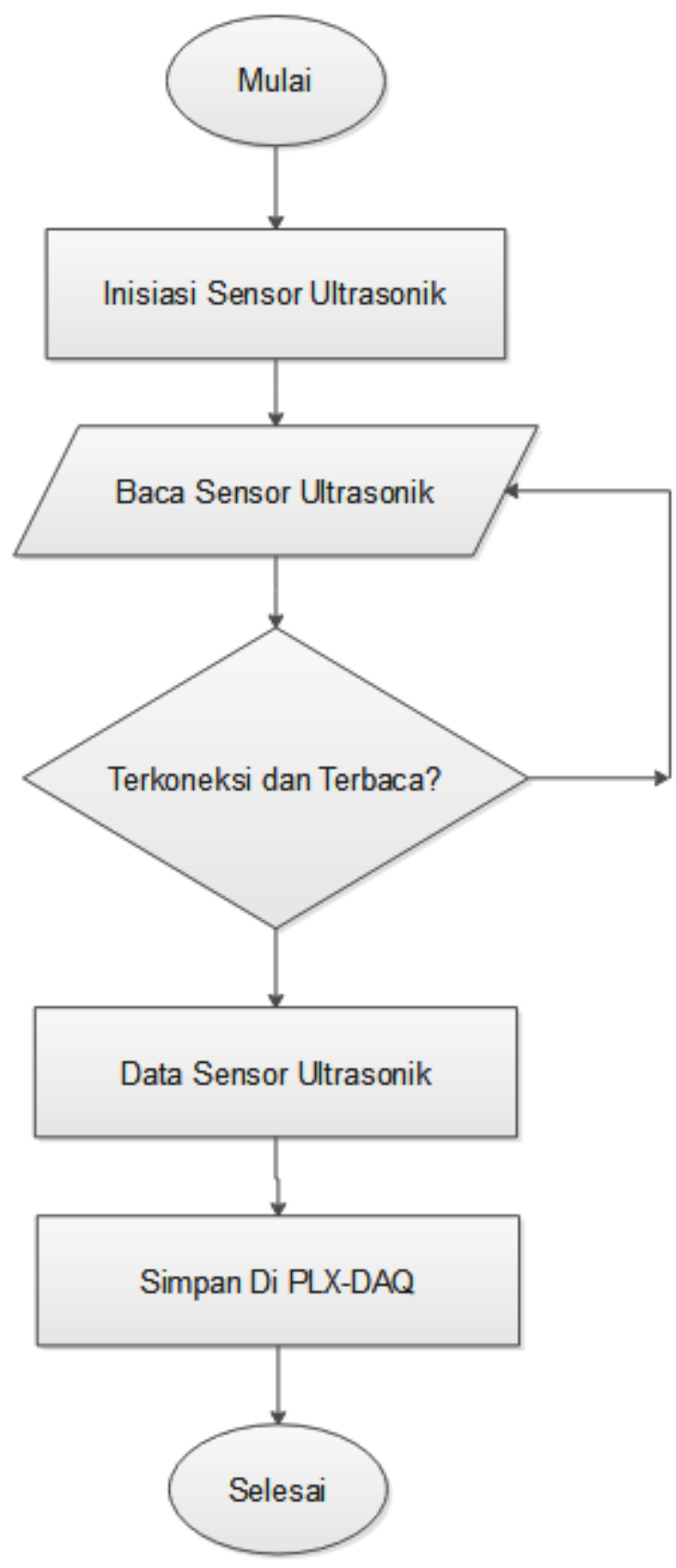

Gambar 6. Tahap Penelitian Secara Keseluruhan

\section{HASIL DAN DISKUSI}

Hasil pengujian dengan larik sensor ultrasonik (dalam hal ini masing-masing sensor disebut dengan A B, C, D, E, F, G, H, I, J, K) dengan variasi jarak 50cm memberikan nilai pembacaan yang lebih baik dari variasi jarak yang lain. Pada gambar 7 dapat ditunjukkan bahwa pada jarak $50 \mathrm{~cm}$ terdapat pola yang lebih seragam dan mendekati dengan standar jarak yang ditentukan dibandingan dengan variasai jarak yang lain. Hasil variasi jarak selain $50 \mathrm{~cm}$ menunjukkan pola naik turun dari pembacaan setiap sensor dalam sistem larik sensor ultrasonik ini. Hal ini dapat dilihat dari perbandingan pembesaran gambar 7 di gambar 8 . 


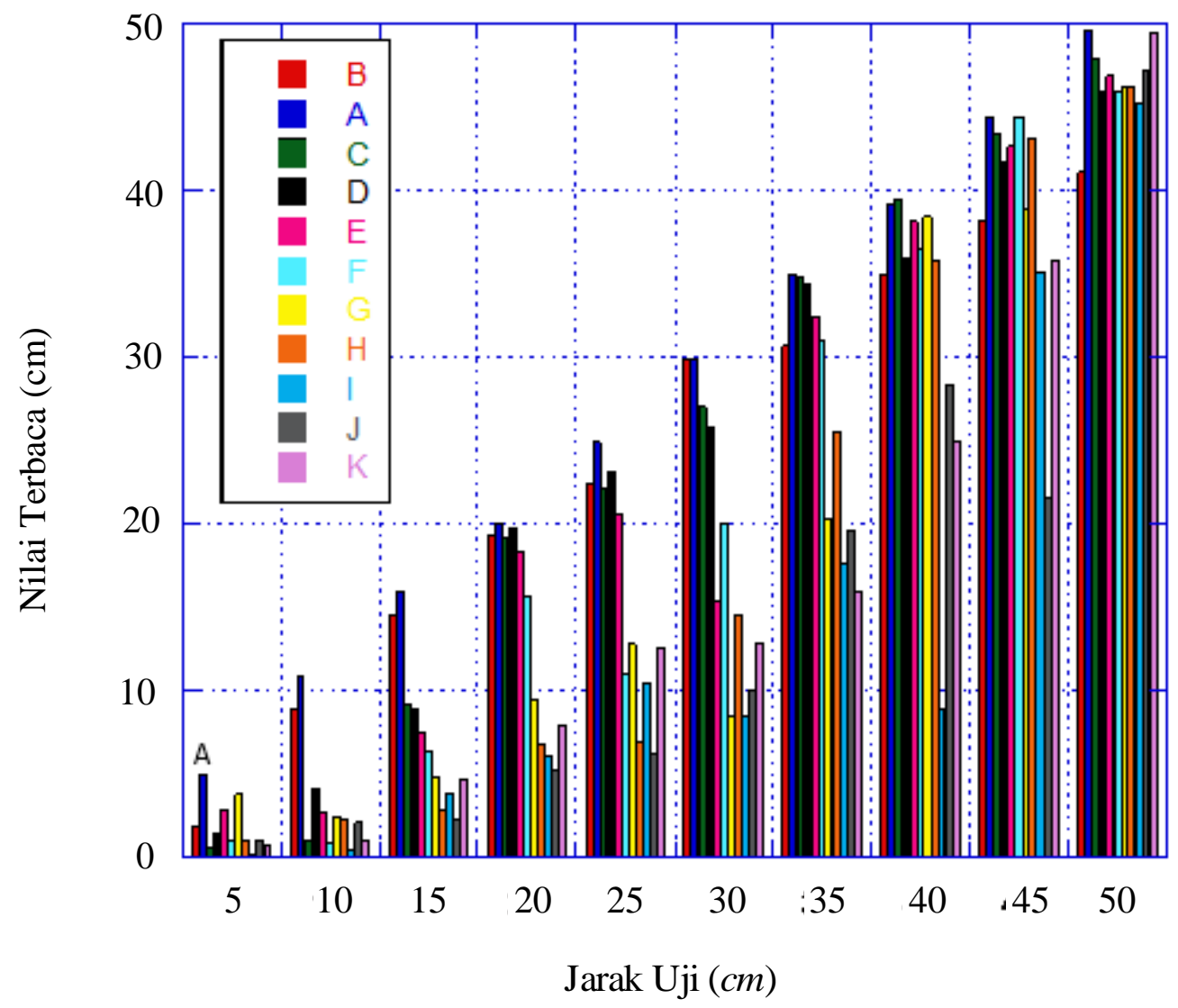

Gambar 7. Grafik Hubungan Jarak Uji vs Nilai Sebenarnya untuk Seluruh Sensor

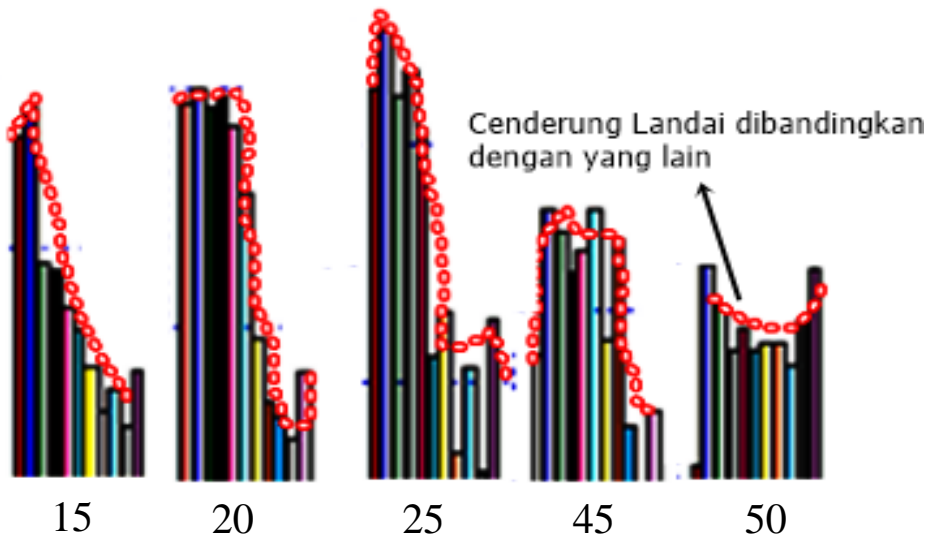

Gambar 8. Grafik Perbandingan Pola Pembacan Sensor dibeberapa Jarak Titik Uji

Data pengujian kemudian dapat diperkuat dengan gambar 9 yang menunjukkan nilai error untuk setiap sensor diberbagai jarak uji. Dapat terlihat bahwa pada jarak $50 \mathrm{~cm}$ setiap sensor dalam sistem larik mempunyai error yang lebih kecil dibandingkan dengan yang lain. Hal ini juga diperkuat dengan adanya rata-rata error setiap sensor dalam sistem larik pada setiap variasi posisi. Tabel 1 menunjukkan nilai rata-rata error terbesar adalah $67.8 \%$ dan yang paling kecil adalah $7.1 \%$ dijarak $50 \mathrm{~cm}$. Grafik rata-rata error ditunjukkan pada gambar 10. 


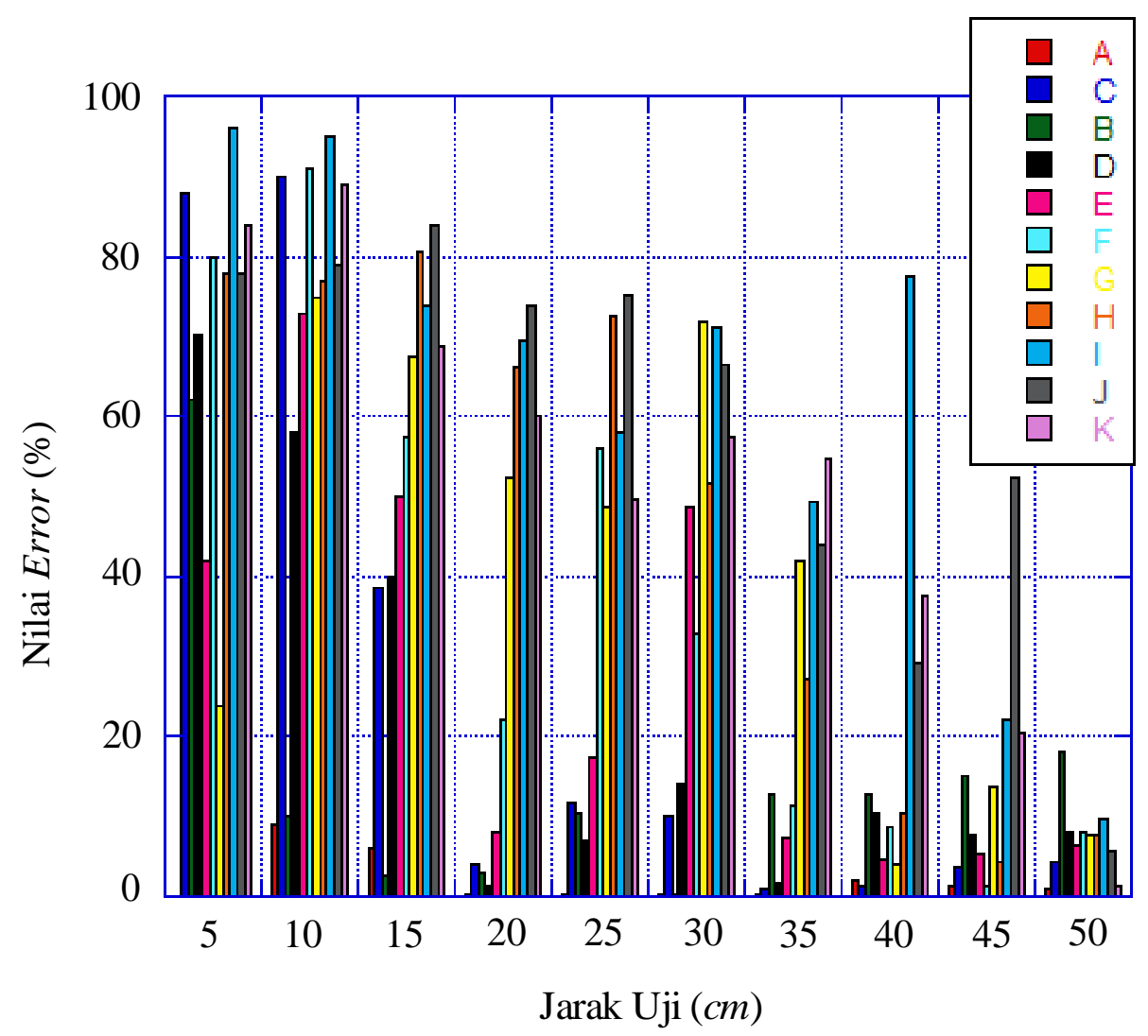

Gambar 9. Grafik Hubungan Jarak Uji vs Nilai Error untuk Setiap Sensor

Tabel 1. Jarak Uji vs Rata-rata Error Larik Sensor Ultrasonik

\begin{tabular}{cc}
\hline Jarak Uji (cm) & $\begin{array}{c}\text { Rata-rata Error Larik } \\
\text { Sensor Ultrasonik (\%) }\end{array}$ \\
\hline 5 & 63.8 \\
10 & 67.8 \\
15 & 51.8 \\
20 & 32.8 \\
25 & 37.0 \\
30 & 38.6 \\
35 & 22.9 \\
40 & 18.1 \\
45 & 13.4 \\
50 & 7.1 \\
\hline
\end{tabular}




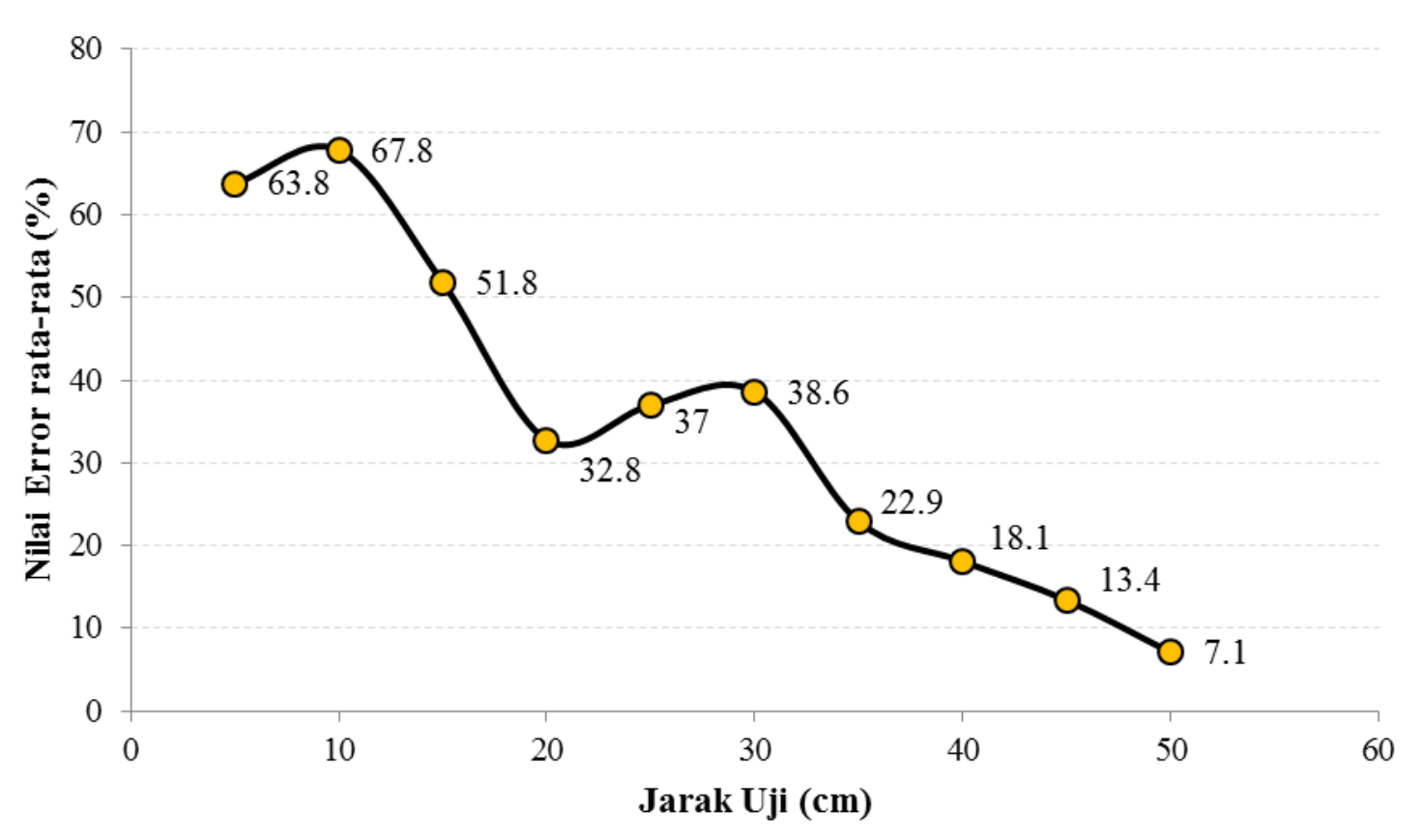

Gambar 10. Grafik Hubungan Antara Jarak Uji dengan nilai rata-rata error

Hasil peneltian juga menunjukkan karakteristik pembacaan masing-masing sensor. Walaupun dari gambar 10 terlihat rata-rata error yang paling kecil adalah di jarak $50 \mathrm{~cm}$. Namun, disetiap variasi jarak terdapat karakteristik sensor ultrasonik itu sendiri. Dari tabel 2 dapat diketahui bahwa pembacaan sensor A (letak sensor paling atas) lebih bagus dibandingkan dengan sensor yang lain (B, C, D, dst.). Hal ini bisa saja terjadi karena sensor A sebelum terpengaruh oleh pembacaan sensor yang lain dibawahnya. Sedangkan yang lain, sudah saling mempengaruhi sehingga terjadi noise. Namun hal ini masih memerlukan penelitian lebih lanjut lagi.

Tabel 2. Grafik Hubungan Pembacaan Sensor dengan Nilai Rata-rata Error

\begin{tabular}{cc}
\hline Sensor & $\begin{array}{c}\text { Nilai rata-rata } \\
\text { error }(\%)\end{array}$ \\
\hline A & 2.1 \\
B & 14.7 \\
C & 25.3 \\
D & 21.8 \\
E & 26.3 \\
F & 36.9 \\
G & 40.7 \\
H & 47.6 \\
I & 62.2 \\
J & 58.8 \\
K & 52.3 \\
\hline
\end{tabular}

\section{KESIMPULAN}

Dari hasil Pengujian menunjukkan bahwa pembacan sensor yang baik dengan rata-rata error yang kecil adalah pada jarak $50 \mathrm{~cm}$. Persentase error yang dihasilkan adalah sebesar 7.1\%. Kemudian 
dari sebelas sensor yang digunakan dan dari berbagai variasi jarak yang dilakukan, pembacaan terbaik adalah pada sensor A dengan nilai rata-rata error sebesar $2.1 \%$.

\section{UCAPAN TERIMA KASIH}

Terimakasih kepada Departemen Teknik Elektro dan Informatika Sekolah Vokasi UGM atas segala bantuan dan support melalui skema penelitian sehingga penelitian ini dapat berlangsung.

\section{DAFTAR PUSTAKA}

Arifin, J., Zulita, L.N., Hermawansyah. (2016). Perancangan Murottal Otomatis Menggunakan Mikrokontroller Arduino Mega 2560. Jurnal Media Infotama, Vol. 12, No. 1.

Alawiyah, A. dan Al Tahtawai, A.R,.(2017). Sistem Kendali dan Pemantauan Ketinggian Air Pada Tangki Berbasis Sensor Ultrasonik. Jurnal Ilmiah Manajemen Informatika dan Komputer. Vol.01, No.1.

Arief, U.M.(2011).Pengujian Sensor Ultrasonik PING untuk Pengukuran Level Ketinggian dan Volume Air. Jurnal Ilmiah Enjiniring UNHAS, Vol. 09.

Fachri, M.R., Sara, I.D. dan Away, Y.(2015). Pemantauan Parameter Panel Surya Berbasis Arduino Secara Real Time. Jurnal Rekayasa Elektrika, Vol. 11, No. 4, hal 123-128.

Fikri, M.A., Erwanto, D., Yuliana, D.E.(2018). Rancang Bangun Alat Prediksi Kondisi Tubuh Ideal Menggunakan Metode Fuzzy Logic Sugeno. Jurnal Sistem Kendali Tenaga Elektronika Telekomunikasi-Komputer (SETRUM), Vol. 7, No. 1.

Iskandar, A., Muhajirin dan Lisah. (2017). Sistem Keamanan Pintu Berbasis Arduino Mega. Jurnal Informatika UPGRIS. Vol.3, No.2.

Junaidi, E., Waslaluddin, W., Hasanah, L.(2015). Rancang Bangun Scanner 3D Menggunakan Sensor Ultrasonik dengan Tampilan Realtime Berbasis Mikrokontroler. Fibusi. Jurnal Online Fisika, Vol. 3, No. 2.

Maria, P.S. dan Susianti, E.(2019). Uji Kinerja Surface Scanner 3D Menggunakan Sensor VL53L0X dan Mikrokontroler ATMEGA8535. Jurnal Teknik Elektro, Vol . 11, No.1.

Mira, A., dan Swarnalatha, R.(2018). Implementation of an Industrial Automation System Model Using An Arduino, Jurnal of Engineering Science and Technology, Vol 13. No.12.

Munir, M.M, Billah, M.A., Surachman, A., dkk.(2015). Design of 3D Scanner for Surface Contour Mapping by Ultrasonik Sensor. AIP Conference Proceeding, 1656, 040006.

Ohoiwutun.(2018). Analisis dan Perancangan Smart Dump Menggunakan Arduino Mega 2560 Rev 3 dan GSM SIM900, Jurnal Elektro Luceat. Vol. 4, No.1.

Pindrayana, K., Borman, R.I., Prasetya, B., Samsuji, S.(2018).Prototipe Pemandu Parkir Mobil Dengan Output Suara Manusia Menggunakan MIkrokontroler Arduino Uno, Jurnal Ilmiah Pendidikan Teknik Elektro. Vol.2., No.2. hal 71-82.

Puspasari, F., Fahrurrozi, I., Satya, T.P., dkk.(2019). Sensor Ultrasonik HCSR04 Berbasis Arduino Due untuk Sistem Monitoring Ketinggian, Jurnal Fisika dan Aplikasinya, Vol. 15, No.2.

Renaldi, L., Hadiyoso, S., Ramdan, D.N.(2018). Purwarupa Radar Sebagai Pendeteksi Benda Diam Menggunakan Ultrasonik. ELKOMIKA. Vol. 06, No. 3., hal. 317-327.

Walter, C., dan Schweinzer, H. (2015). Application of A compact ultrasonik 3D Sensor for Recognition of Shape and Orientation of Objects. doi :10.5162/sensor2015/A3.2 